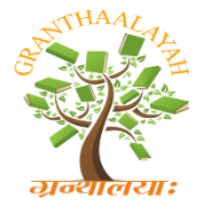

\author{
INTERNATIONAL JOURNAL OF R
GRANTHAALAYAH \\ A knowledge Repository
}

Science

\title{
CRITICAL SOIL OPTIMIZATION STRATEGY THROUGH THE UTILIZATION OF AGRICULTURAL WASTE, LIVESTOCK, AND FISHERIES
}

\author{
I Ketut Widnyana ${ }^{1}$, IGN Alit Wiswasta ${ }^{1}$, Putu Eka Pasmidi Ariati ${ }^{1}$ \\ ${ }^{1}$ Faculty of Agriculture, Mahasaraswati University, Denpasar
}

\begin{abstract}
Critical land area in Indonesia was recorded 23.25 million ha in 2000, and increased to 77.8 million ha in 2007, efforts are needed to optimize it. However, the existence of agricultural waste, livestock waste and sewage abundant fishery potential to increase soil fertility has not been utilized to the maximum. This study aimed to determine the macro nutrient content available in waste after the fermentation process. This research is an experimental research conducted in a laboratory to find out the content of: $\mathrm{N}, \mathrm{P}, \mathrm{K}, \mathrm{C} / \mathrm{N}$ ratio. The method for making liquid organic fertilizer is fermentation for one month using EM4 effective microorganisms, then analyzed using Spectrometry and Titrimetry Kjeldahl. The results showed that the highest $\mathrm{N}$ content was in bio urine fermentation $(0.126 \%)$, fish waste $(0.035 \%)$ and mixed waste $(0.028 \%)$; The highest $\mathrm{P}$ was found in cattle rumen $(7.239 \mathrm{mg} / \mathrm{L})$, bio urine $(5.234 \mathrm{mg} / \mathrm{L})$, and seaweed $(4.689 \mathrm{mg} / \mathrm{L})$, and highest $\mathrm{K}$ was found in fruit waste $(7,801 \mathrm{mg} / \mathrm{L})$. The highest $\mathrm{C} / \mathrm{N}$ ratio was found in seaweed $(55,643 \%)$ and fruit waste $(27,857 \%)$. The conclusion is that agricultural waste, livestock waste, and fisheries waste after 1 month of fermentation contain adequate nutrients for optimizing critical land.
\end{abstract}

Keywords: Liquid Organic Fertilizer; Crop Waste; Livestock Waste; Fish Waste.

Cite This Article: I Ketut Widnyana, IGN Alit Wiswasta, and Putu Eka Pasmidi Ariati. (2019). "CRITICAL SOIL OPTIMIZATION STRATEGY THROUGH THE UTILIZATION OF AGRICULTURAL WASTE, LIVESTOCK, AND FISHERIES." International Journal of Research - Granthaalayah, 7(12), 77-85. 10.29121/granthaalayah.v7.i12.2019.302.

\section{Introduction}

Some institutions provide different definitions of degraded land. Critical land is land that is not in accordance with the use and its ability to have experienced or in the process of physical, chemical, and biological damage which ultimately endangers the hydrological function, agricultural production, settlement and socio-economic life (Muljadi \& Soepraptohardjo, 1975). Whereas the Ministry of Forestry defines critical land as land that is no longer able to function as a medium for regulating water management and good agricultural production elements, characterized by a state 
of vegetation cover of less than 25 percent, topography with a slope of more than 15 percent, and / or characterized by symptoms sheet erosion, and gully erosion (Ministry of Forestry, 2005)

The area of critical land in Bali reaches 44,669.78 ha, of which 16,323.68 ha is in the forest area and 28,346.10 ha is agricultural area. The regencies with the most extensive critical land are Karangasem 13,188.25 ha, Buleleng 7,494.81 ha, and Klungkung 13,710.92 ha. One strategy that can be implemented to optimize the potential of degraded land is to add adequate organic matter to the soil. Complete organic matter content of the nutrients is a result of the fermentation of organic waste from agricultural waste, livestock waste, and fishery waste. The presence of complete nutrient content and the indigenic microorganisms it contains when added to critical soils will be able to maintain soil fertility, increase soil microbial populations and preserve the environment.

Besides that organic matter can increase the soil's absorption of water, strengthen the stability of aggregate and soil structure and increase the buffering power of fertilizer, which can ultimately increase fertilizer efficiency (Rinsema, 1983)

Each agro-ecosystem area in Bali produces various agricultural wastes such as vegetable waste, fruits, post-harvest waste; likewise livestock waste such as solid and liquid livestock manure (bio urine). In some areas there is also fisheries waste such as fish oil, bone meal and fish waste. These wastes if properly fermented and formulated in the form of solid and liquid organic fertilizers will be very beneficial in increasing soil fertility and increasing my grasp of groundwater. This is very much needed in an effort to optimize critical land in Bali and also other regions in Indonesia. Utilization of wastes originating from agricultural areas and returned to the area after formulation in the form of solid and liquid organic fertilizers is one of the environmentally friendly agricultural strategies directed in addition to meeting local agricultural needs, is also aimed at minimizing the entry of plant pests from outside the area.

Based on the above, it is necessary to conduct research on the utilization of agricultural, livestock and fisheries waste as liquid organic fertilizer to increase the productivity of critical land in Bali so as to reduce dependence on chemical fertilizers and limited water to sustainable agriculture

\section{Materials and Methods}

\section{Materials and Tools}

The materials used in this study are organic waste from agriculture, livestock waste, and fisheries waste, namely: fruit waste, vegetable waste, bio urine, beef rumen contents, fish stew waste, and seaweed. The permentor used is EM4. The tools used are: buckets, scales, plastic barrels, alluminium foil, ovens, plastic bags and stationery that support the experiment.

\section{Making Liquid Organic Fertilizer}

In this study, 7 (seven) types of POC (liquid organic fertilizer) were made from different waste sources, namely: 1 . fruit waste, 2 . vegetable waste, 3 . bio urine, 4 . beef rumen contents, 5 . fish stew waste, 6. seaweed. In 100 liters of water added with $10 \mathrm{~kg}$ of material / waste), added with 1 L EM4 permentor. The fermentation process is carried out for 1 month, then harvested. 
Nutrient Content Analysis.

This research is an experimental research conducted in a laboratory to find out the content of: $\mathrm{N}$, $\mathrm{P}, \mathrm{K}, \mathrm{C} / \mathrm{N}$ ratio, and micro elements such as $\mathrm{Fe}, \mathrm{Ca}, \mathrm{S}$, and $\mathrm{Mg}$. After one month of fermentation using the EM4 microorganism effective, then the nutrient content analysis was carried out using Spectrometry and Kjeldahl's Titrimetry.

\section{Results and Discussions}

\section{Analysis of Nutrient Content from Bio Urine Fermentation and Beef Rumen Contents}

Bio urine and cattle rumen contents are livestock / livestock waste products that are often thrown away, almost never used as fertilizer for plants. Every farmer in Bali always has at least 2 cows capable of producing at least 10 liters of bio urine / day, so that in a year it reaches 3,650 liters of bio urine. Likewise, the contents of the rumen of cattle in abattoirs are not utilized at all. After 30 days of fermentation the nutrient content of bio urine and rumen of cattle is presented in Table 1.

Table 1: Analysis of nutrient content from bio urine fermentation and beef rumen contents

\begin{tabular}{|l|l|l|l|c|c|}
\hline No & Parameters & Methods & \multirow{2}{*}{ Unit } & \multicolumn{2}{|c|}{ Nutrient Content } \\
\cline { 4 - 6 } & & & & Bio Urine & Beef Rumen \\
\hline 1 & Iron (Fe) & Spectrometry & $\mathrm{mg} / \mathrm{L}$ & 1,282 & 3,673 \\
\hline 2 & Calcium $(\mathrm{Ca})$ & Spectrometry & $\mathrm{mg} / \mathrm{L}$ & 6,45 & $<0,001$ \\
\hline 3 & Sulfide $(\mathrm{S} 2-)$ & Spectrometry & $\mathrm{mg} / \mathrm{L}$ & 390.24 & 10,851 \\
\hline 4 & Magnesium $(\mathrm{Mg})$ & Spectrometry & $\mathrm{mg} / \mathrm{L}$ & 27,11 & 22,224 \\
\hline 5 & Nitrogen $(\mathrm{N})$ & Kjeldahl's Titrimetry & $\%$ & 0,126 & 0,014 \\
\hline 6 & Posphor (P) & Spectrometry & $\mathrm{mg} / \mathrm{L}$ & 5,234 & 7,239 \\
\hline 7 & Potassium (K) & Spectrometry & $\mathrm{mg} / \mathrm{L}$ & $<0,001$ & $<0,001$ \\
\hline 8 & C / N ratio & Kjeldahl's Titrimetry & $\%$ & 6,183 & 27,821 \\
\hline
\end{tabular}

Judging from the macro nutrient content $(\mathrm{N}, \mathrm{P}, \mathrm{K})$, the $\mathrm{N}$ content in bio urine is very high at $0.126 \%$ or 8 times more than the $\mathrm{N}$ content in the rumen content of cattle, and 4 times more than the $\mathrm{N}$ content of a mixture of all ingredients.

\section{Analysis of Nutrient Content Resulting from The Fermentation of Fish and Seaweed Waste}

Fish waste meant in this case is boiled water of mackerel type fish whose presence is very much in the fish auction area in Pengambengan Jembrana Bali which has been causing a foul odor because it was discarded by the fishermen around their business premises. This fish cooking water can be taken freely because it is not used at all by the community. Seaweed used in this study is as a nutrient supplementation in the manufacture of liquid organic fertilizer. Seaweed used is seaweed that grows naturally around the village of Serangan in the Badung regency of Bali. Results of fish and seaweed waste analysis are presented in Table 2.

Table 2: Results of nutrient content analysis results from the fermentation of fish waste and seaweed

\begin{tabular}{|l|l|l|c|c|c|}
\hline No. & Parameter & Methods & Unit & \multicolumn{2}{|c|}{ Nutrient Content } \\
\cline { 5 - 6 } & & & & Fish Waste & Seaweed \\
\hline 1 & Iron $(\mathrm{Fe})$ & Spectrometry & $\mathrm{mg} / \mathrm{L}$ & 1,785 & 1,754 \\
\hline
\end{tabular}




\begin{tabular}{|l|l|l|l|c|c|}
\hline 2 & Calcium $(\mathrm{Ca})$ & Spectrometry & $\mathrm{mg} / \mathrm{L}$ & $<0,001$ & $<0,001$ \\
\hline 3 & Sulfide $(\mathrm{S} 2-)$ & Spectrometry & $\mathrm{mg} / \mathrm{L}$ & 580,64 & $<0,001$ \\
\hline 4 & Magnesium $(\mathrm{Mg})$ & Spectrometry & $\mathrm{mg} / \mathrm{L}$ & 13,909 & 20,663 \\
\hline 5 & Nitrogen $(\mathrm{N})$ & Kjeldahl's Titrimetry & $\%$ & 0,035 & 0,014 \\
\hline 6 & Posphor $(\mathrm{P})$ & Spectrometry & $\mathrm{mg} / \mathrm{L}$ & 4,233 & 4,689 \\
\hline 7 & Potassium $(\mathrm{K})$ & Spectrometry & $\mathrm{mg} / \mathrm{L}$ & $<0,001$ & $<0,001$ \\
\hline 8 & C / N ratio & Kjeldahl's Titrimetry & $\%$ & 22,257 & 55,643 \\
\hline
\end{tabular}

Data from the nutrient content analysis in Table 2 shows that the results of fish waste fermentation have a very prominent sulfide content of $580.64 \mathrm{mg} / \mathrm{L}$ while seaweed is $<0.001 \mathrm{mg} / \mathrm{L}$. Other nutrient content that is also prominent is the $\mathrm{N}$ nutrient content which reaches $0.035 \%$ or $250 \%$ more than the $\mathrm{N}$ content in seaweed. Judging from the $\mathrm{C} / \mathrm{N}$ ratio of $22.257 \%$ or half of seaweed, shows that fish waste can be broken down faster than seaweed so that it is faster in preparing nutrients. This shows that fish waste is very potential as a source of $\mathrm{N}$ in liquid organic fertilizer.

\section{Analysis of Nutrient Content from Fruit and Vegetable Waste Fermentation}

Many fruit wastes are scattered not only in the fruit market but also under fruit trees, such as oranges, mangoes, snake fruit, pineapples, and other fruits, especially during the main harvest. Likewise, vegetable waste is wasted in the vegetable garden or in the vegetable market. During this time it has never been used even thrown away. The results of the analysis of the nutrient content of the fruit and vegetable waste are presented in Table 3.

Table 3: Results of analysis of nutrient content of fermented fruit and vegetable waste.

\begin{tabular}{|l|l|l|l|c|c|}
\hline No. & Parameter & Methods & \multirow{2}{*}{ Unit } & \multicolumn{2}{|c|}{ Nutrient Content } \\
\cline { 4 - 5 } & & & Vegetable Waste & Fruit Waste \\
\hline 1 & Iron $(\mathrm{Fe})$ & Spectrometry & $\mathrm{mg} / \mathrm{L}$ & 0,637 & 1,266 \\
\hline 2 & Calcium $(\mathrm{Ca})$ & Spectrometry & $\mathrm{mg} / \mathrm{L}$ & $<0,001$ & $<0,001$ \\
\hline 3 & Sulfide $(\mathrm{S} 2-)$ & Spectrometry & $\mathrm{mg} / \mathrm{L}$ & 7,043 & $<0,001$ \\
\hline 4 & Magnesium $(\mathrm{Mg})$ & Spectrometry & $\mathrm{mg} / \mathrm{L}$ & 9,879 & 10,165 \\
\hline 5 & Nitrogen $(\mathrm{N})$ & Kjeldahl's Titrimetry & $\%$ & 0,021 & 0,014 \\
\hline 6 & Posphor $(\mathrm{P})$ & Spectrometry & $\mathrm{mg} / \mathrm{L}$ & 2,520 & 3,825 \\
\hline 7 & Potassium $(\mathrm{K})$ & Spectrometry & $\mathrm{mg} / \mathrm{L}$ & $<0,001$ & 7,801 \\
\hline 8 & C / N ratio & Kjeldahl's Titrimetry & $\%$ & 18,571 & 27,857 \\
\hline
\end{tabular}

The data in Table 3 shows that the results of the fermentation of fruit and vegetable waste have different nutrient content. In vegetable waste it has an $\mathrm{N}$ content of $0.021 \%$ or almost double that of fruit waste, but in the $\mathrm{K}$ content it turns out that fruit waste is very prominent at $7.801 \mathrm{mg} / \mathrm{L}$ while in vegetable waste the $\mathrm{K}$ content is undetected or below $0.001 \mathrm{mg} / \mathrm{L}$. likewise fruit waste contains twice the Fe compared to vegetable waste which is $1.266 \mathrm{mg} / \mathrm{L}$. Judging from the C / N ratio in $18.571 \%$ vegetable waste and fruit waste $27.885 \%$, this means that fruit waste requires more time to be decomposed. In general, it can be said that fruit waste is very potential as a source of $\mathrm{K}$ and potential vegetable waste as a source of $\mathrm{N}$. 


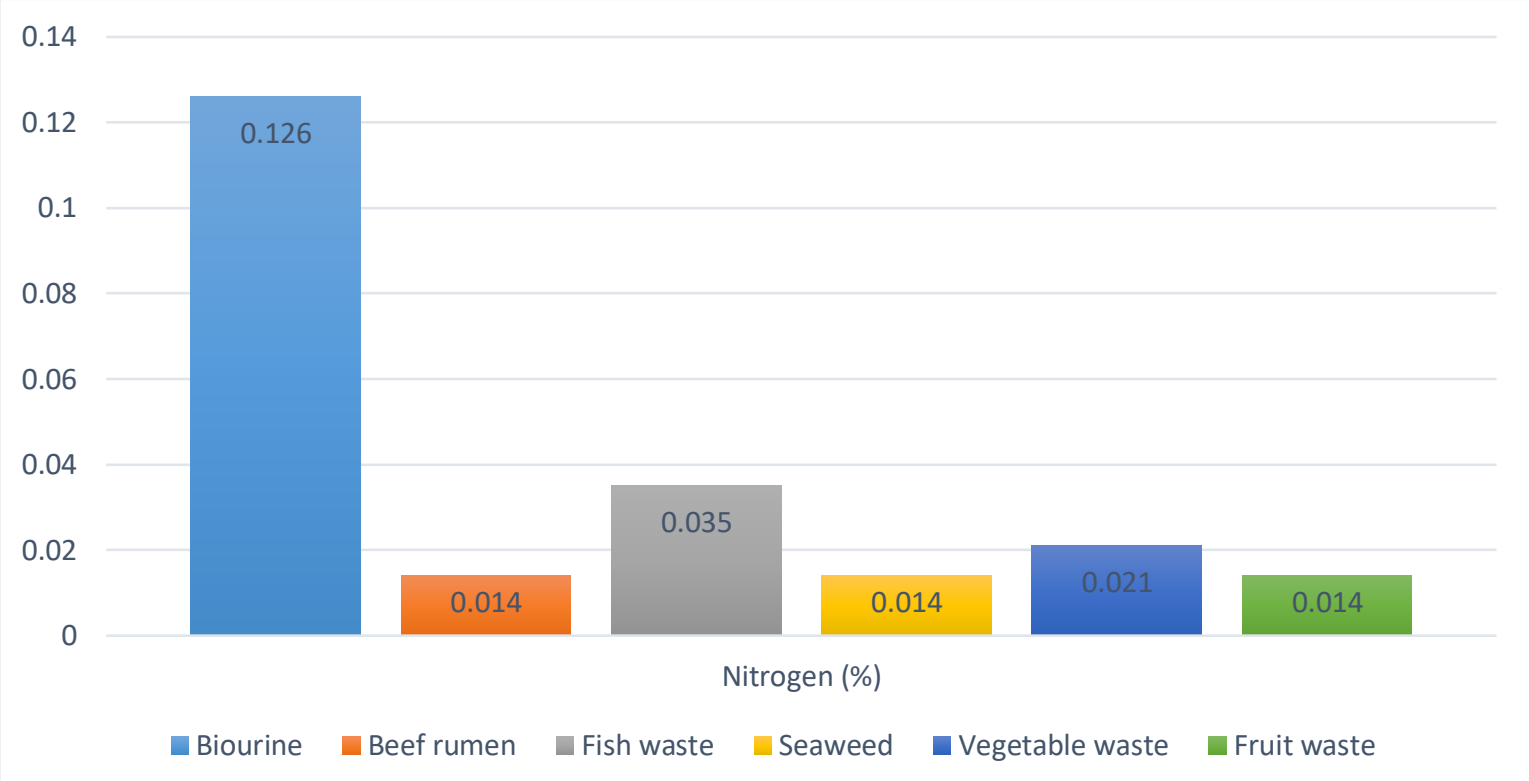

Figure 1: Nitrogen content in various agricultural, livestock and fisheries waste samples

Figure 1 shows that bio urine is the only waste originating from livestock with the highest $\mathrm{N}$ content which is $0.126 \%$, then followed by fish waste (fish cooking water) $0.035 \%$, a mixture of the results of the fermentation of fruit, vegetable, bio urine, cow rumen waste fish, and seaweed is $0.028 \%$, and vegetable waste is $0.021 \%$. The lowest $\mathrm{N}$ content was found in the rumen of cattle, seaweed, and fruit waste at $0.014 \%$.

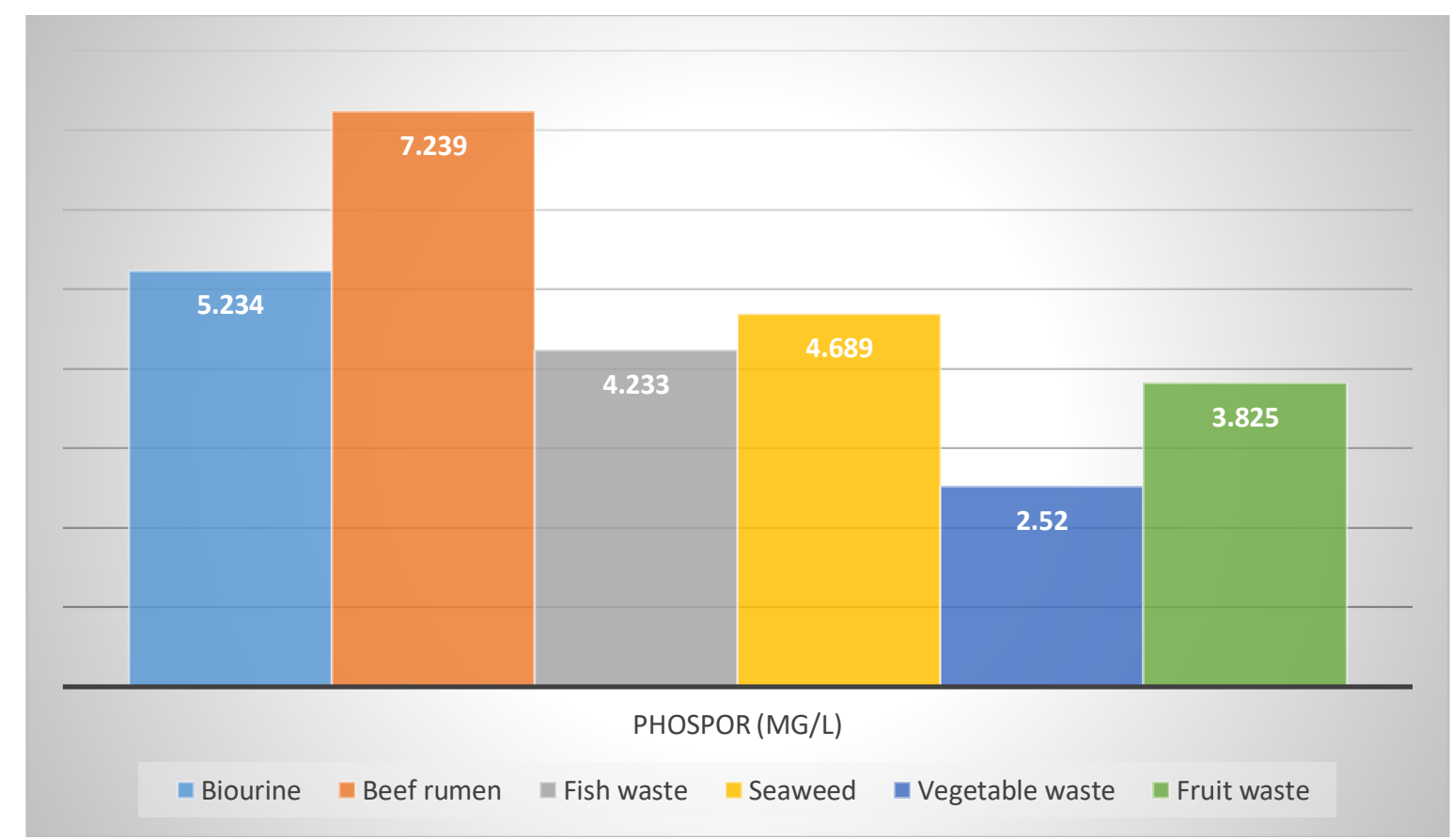

Figure 2: Phosphorus content in various samples of agricultural, livestock and fisheries waste 
Figure 2 shows that all types of waste used in this study are the results of the fermentation of fruit, vegetable, bio urine, rumen cattle, fish, and seaweed waste containing the $\mathrm{P}$ element. The highest $\mathrm{P}$ element content is found in the fermentation results from the rumen content of cattle 7, $239 \mathrm{mg}$ / L, proven with bio urine 5,234 mg / L, and seaweed 4,689 mg / L. The lowest P element content is found in the fermentation of vegetable waste which is $2.52 \mathrm{mg} / \mathrm{L}$.

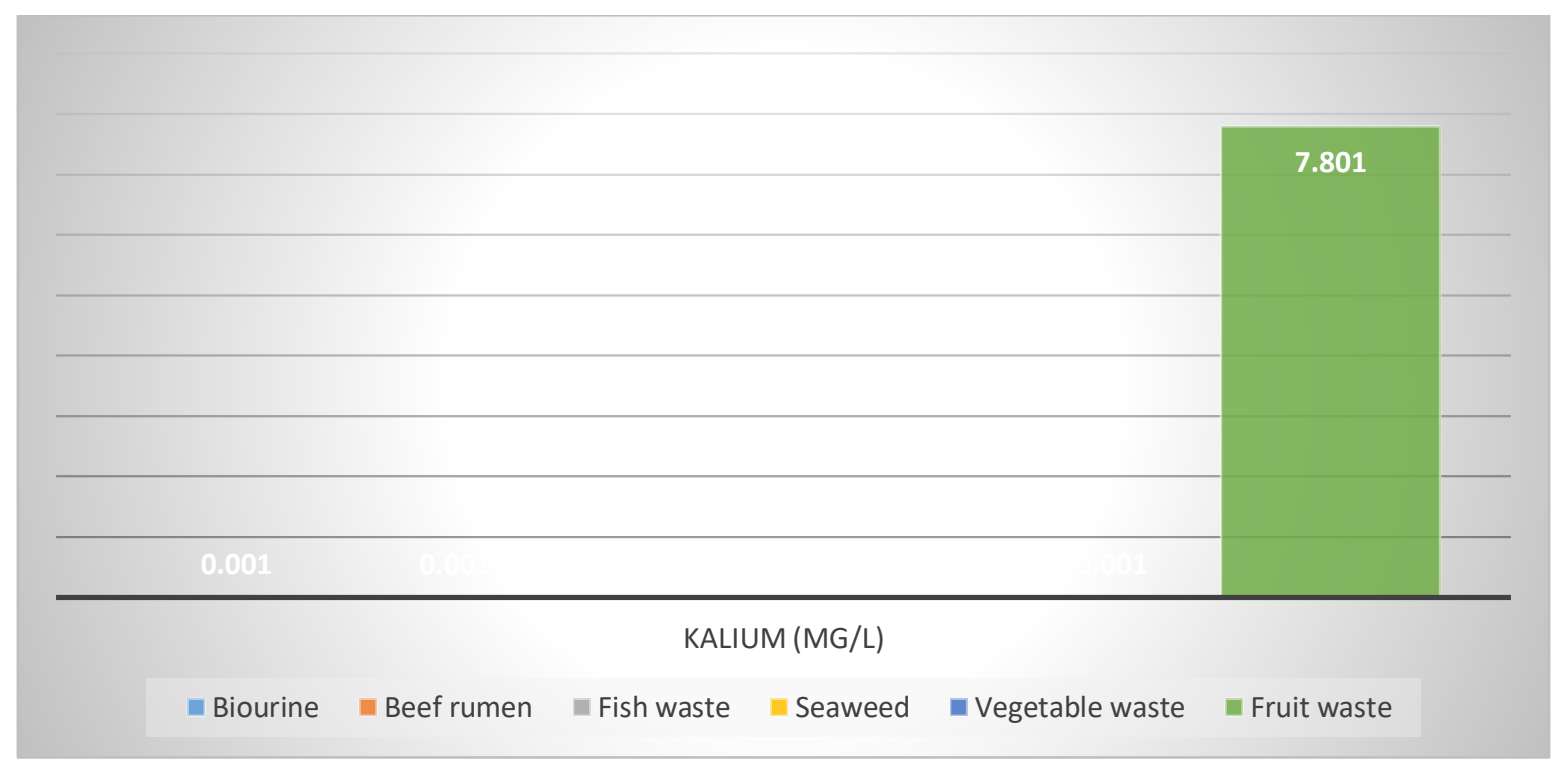

Figure 3: Potassium (K) content in various samples of agricultural, livestock and fisheries waste

Figure 3 shows that the K content of all fruit, vegetable, bio urine, rumen cattle, fish and seaweed fermentation results turned out to be only fruit waste that has a high $\mathrm{K}$ content of 7,801 $\mathrm{mg} / \mathrm{L}$, while the content of other waste K elements not detected or $<0.001 \mathrm{mg} / \mathrm{L}$. In general it can be stated that liquid organic fertilizer from fruit waste has good potential if directed to the flowering or fruiting process of plants.

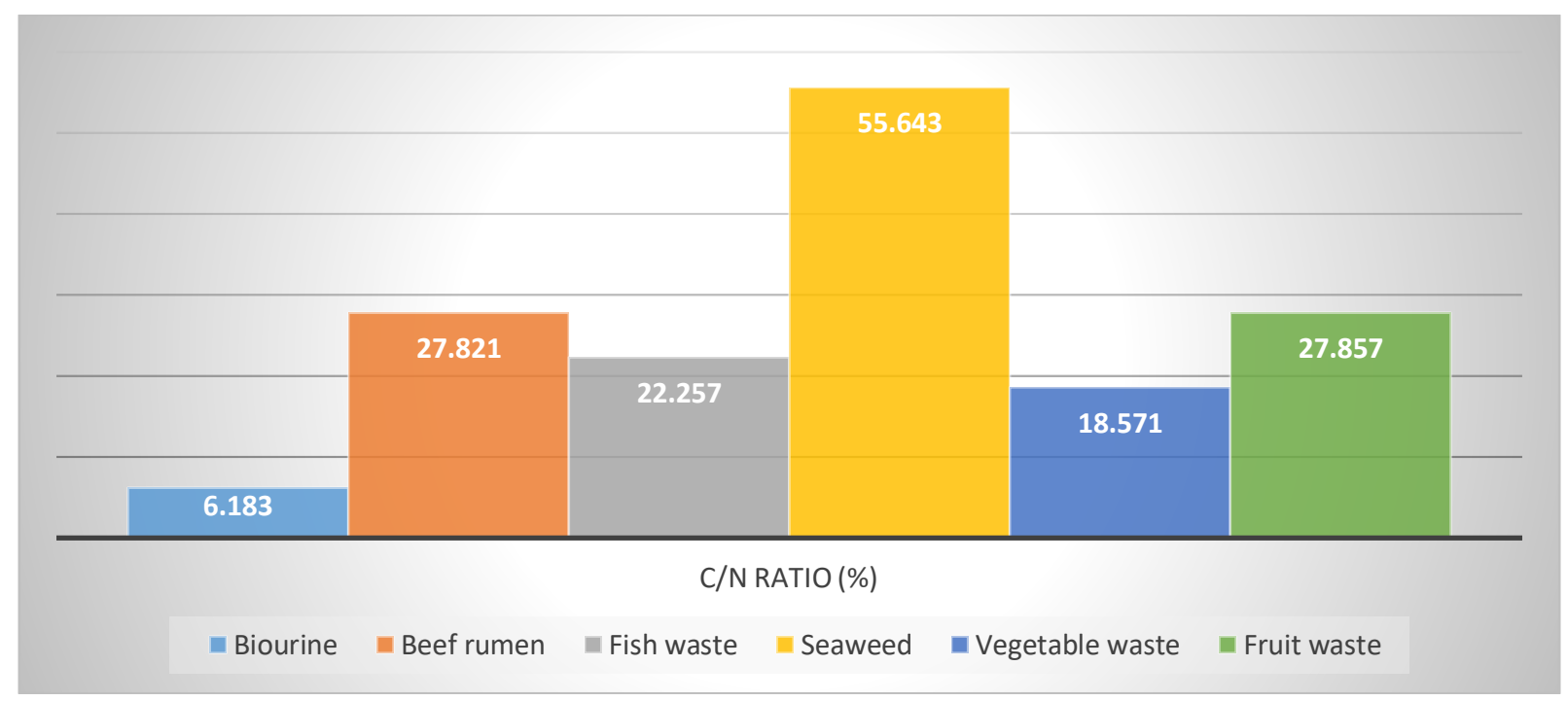

Figure 4: $\mathrm{C} / \mathrm{N}$ ratio content in various samples of agricultural, livestock and fisheries waste 
Figure 4 shows that the content of the $\mathrm{C} / \mathrm{N}$ ratio of each of the results of the fermentation of waste fruit, vegetables, bio urine, rumen cattle, fish, and seaweed are different. The highest $\mathrm{C} / \mathrm{N}$ ratio was found in seaweed waste $55,643 \%$, then followed fruit waste $27,857 \%$ and cattle rumen $27,821 \%$. The higher $\mathrm{C} / \mathrm{N}$ ratio indicates that the waste requires a longer time in the decomposition / decomposition process. The content of a good $\mathrm{C} / \mathrm{N}$ ratio in fertilizer is close to the $\mathrm{C} / \mathrm{N}$ ratio of the soil which is between $15-25 \%$. When viewed from these values, the $\mathrm{C} / \mathrm{N}$ ratio in the bio urine is the $\mathrm{C} / \mathrm{N}$ ratio that is suitable for plant needs. If the fermentation period is extended to a certain time it is likely that the high $\mathrm{C} / \mathrm{N}$ ratio of the waste will decrease. this is in accordance with the opinion of Nur et al. (2016) that the longer the process of making liquid organic fertilizer (composting) will increase the content of $\mathrm{N}, \mathrm{P}$, and $\mathrm{C}$ in the waste sample produced.

In accordance with Minister of Agriculture Regulation No. 2 / Pert. / HK.060 / 2/2006, organic fertilizers are fertilizers consisting mostly or entirely of organic material derived from plant or animal residues that have been engineered in the form of solid or liquid used to supply organic materials, improving the nature of physical, chemical and biological soil (Ministry of Agriculture, 2006).

The process of decomposition (fermentation) of organic material will cause an increase in material temperature. The success of the organic fertilizing process will be followed by an increase in temperature to around $70^{\circ} \mathrm{C}$, then decreasing which indicates the cooling caused by the reduced organic fertilizing process and finally reaching a constant point. This shows the end of the organic fertilization process or the process of making organic fertilizer has been completed. Waste is generally divided into three, namely liquid, solid and gas waste. Most organic wastes come from the agricultural sector with a very abundant amount, but because of the nature of this waste it is easy to rot it will cause odors and contamination of ground water.

Organic waste is very necessary for agricultural soils because the content of organic matter in it is very important. This can be seen from its role that is able to regulate various soil properties, as a buffer supply of nutrients for plants and influence the soil structure (Winarno et al., 1985). Organic waste in rainfed lowland agriculture has a very important role because it can increase aggregate stability, soil structure, water retention capacity and soil erosion and increase the ability to support fertilizer which can ultimately increase fertilizer efficiency (Rochayati \& Sri Adiningsih, 1989). The main source of soil organic matter is crop residues that are returned to the soil and organic fertilizer. The result of the decomposition of organic material will produce humus which is dark brown to black in color, which has the property of being able to bind water four to six times its own weight so as to enhance the ability of the soil to hold water. By binding water to topsoil means reducing percolating water so that washing of nutrients by water can be reduced. In addition, negatively charged colloids can absorb cations so that they can suppress nutrient leaching in soils (Buckman \& Brady, 1982).

There are several benefits derived from the use of organic fertilizers for agricultural land, This is consistent with the results of research Widnyana, et al. 2018, the treatment of green mustard with organic fertilizer give real effect to the very real interaction on plant height, leaf number, fresh weight, oven dry weight, and plant fresh weight per hectare). These benefits are: a) provide nutrients for plants so that efficiency occurs in the use of chemical fertilizers, b) improve soil 
structure, c) increase cation exchange capacity, d) increase the ability of the soil to retain water, e) increase soil biological activity, f) increase acidity soil $\mathrm{pH}, \mathrm{g}$ ) increase the availability of micro elements and the most important thing today is $\mathrm{h}$ ) does not cause environmental problems (Hakim, et al. 1986). There are several benefits to be gained from agriculture using organic fertilizers: 1) the food produced is safe and nutritious enough to improve public health, 2) farmers' income increases, 3) for farmers creating a safe and healthy work environment, 4) all forms of pollution from agricultural activities can be minimized, 5) the productivity of agricultural land in the long run increases and is maintained as well as the preservation of natural resources and the environment is maintained and 6) the creation of new jobs. Liquid organic fertilizer generally does not damage the soil and plants although it is used as often as possible because the fertilizer solution given to the soil surface can be used directly by plants (Hadisuwito, 2007).

\section{Conclusions and Recommendations}

1) The results of fermentation from agricultural, livestock and fish waste have different nutrient content.

2) The highest $\mathrm{N}$ content is in the results of bio urine fermentation $(0.126 \%)$, fish waste $(0.035 \%)$ and mixed waste $(0.028 \%)$; the lowest $\mathrm{N}$ content was found in the results of the rumen fermentation of cattle, seaweed, and fruit waste respectively $0.014 \%$.

3) The highest $P$ content is found in cattle rumen $(7.239 \mathrm{mg} / \mathrm{L})$, bio urine $(5.234 \mathrm{mg} / \mathrm{L})$, and seaweed $(4.689 \mathrm{mg} / \mathrm{L})$, and the lowest $\mathrm{P}$ content is found in vegetable waste $(2.52 \mathrm{mg}$ / L) L)

4) The highest $\mathrm{K}$ content is found in fruit waste (7, $801 \mathrm{mg} / \mathrm{L})$, and all other waste fermentation products have a $\mathrm{K}$ content below $0.001 \mathrm{mg} / \mathrm{L}$

5) The highest $\mathrm{C} / \mathrm{N}$ ratio is found in seaweed $(55,643 \%)$, mixed waste $(47,964 \%)$ and fruit waste $(27,857 \%)$; and the lowest is in bio urine which is $6.183 \%$.

\section{Acknowledgments}

1) To the Ministry of Technology Research and Higher Education for the research costs of the 2019 fiscal year

2) Unmas Denpasar Rector and Dean of the Faculty of Agriculture of facilities and permission given

3) The research team and farmers involved in the research.

\section{References}

[1] Anwar, S. 2007. Critical Land Area in Indonesia. Information is conveyed to the stakeholders, so that it can be used properly. Direktorat Pengelolaan Daerah Aliran Sungai, Ditjen RLPS, Jakarta. (in Bahasa)

[2] Buckman, H.O., Brady, N.C. 1982. Soil Science. Jakarta: Bhratara Karya Aksara (translation). 788 pp.

[3] Ministry of Agriculture, 2006. Registered Fertilizer, Directorate General of Food Crops, Directorate of Production Facilities, Jakarta (in Bahasa)

[4] Hakim, H., Nyakpa, M.Y., Lubis, A.M., Nugroho, Saul, S.G., Pika, R., Go Ban Hong, Bailey 1986. Fundamentals of Soil Science. Lampung: Lampung University. 488 pp. 
[5] Muljadi, D., and M. Soepraptohardjo. 1975. Issues on Area Data and Distribution of Critical Lands. Symposium on Prevention and Restoration of Critical Land in the Context of Regional Development. Jakarta, 1975. (in Bahasa)

[6] Nur, Thoyib; Rizali Noor, A; Elma 2016. Making Liquid Organic Fertilizer from Household Organic Waste with the addition of EM4 (Effective Microorganisms) Bioactivators. Chemical Engineering Study Program, Faculty of Engineering, Lambung Mangkurat University. Conversion, Volume 5 No. 2, October 2016

[7] Rinsema, W.T. 1983. Fertilizers and how to fertilize. Jakarta: Bhratara Karya Aksara. (in Bahasa)

[8] Setyorini, D., Saraswati, R., Anwar, E.K. 2006. Organic fertilizer. Bogor: Agricultural Research and Development Agency. Pages 11 - 40. (in Bahasa)

[9] Rochayati and Sri Adiningsih. 1989. Conservation of Organic Materials through Alley Cropping in rain-fed rice fields. Jakarta: Agricultural Research and Development Agency. Page 8. (in Bahasa)

[10] Sutanto, R. 2002. Application of Organic Agriculture. Yogyakarta: Canisius. Pages 46 - 87. (in Bahasa)

[11] Hadisuwito, S. 2007. Making Liquid Compost Fertilizer, Third ed, Agromedia Pustaka, Jakarta. (in Bahasa)

[12] Widnyana, IK., IW. Seputra Kuspianta; and P. Lasmi Yulianthi Sapanca, 2018. Effect of seed soaking with Bacillus sp and organic fertilizer on growth of mustard green (Brassica juncea L.). Asian J Agri \& Biol. 2018;6(2):204-209.

[13] Winarno, F.G., Budiman. A.F.S., Silitonga, T., Soewardi, B. 1985. Agricultural Product Waste. Jakarta: Monograph. Office of the Deputy Minister of Food Affairs for Increasing Food Production. Pp. 243-254. (in Bahasa)

\footnotetext{
*Corresponding author.

E-mail address: widnyanaketut@ gmail.com
} 